\title{
Commiphora myrrha inhibits itch-associated histamine and IL-31 production in stimulated mast cells
}

\author{
JAE YOUNG SHIN ${ }^{1 *}$, DENIS NCHANG CHE ${ }^{1,2^{*}}$, BYOUNG OK CHO $^{1,3^{*}}$, \\ HYUN JU KANG ${ }^{3}$, JISU KIM ${ }^{1}$ and SEON IL JANG ${ }^{1,3}$ \\ ${ }^{1}$ Department of Health Management, Jeonju University, Jeonju, Jeollabuk 55069; \\ ${ }^{2}$ Department of Food Science and Technology, Chonbuk National University, Jeonju, Jeollabuk 54896; \\ ${ }^{3}$ Research Institute, ATO Q\&A Co., Ltd., Jeonju, Jeollabuk 54840, Republic of Korea
}

Received July 13, 2018; Accepted May 16, 2019

DOI: $10.3892 /$ etm.2019.7721

\begin{abstract}
Commiphora myrrha (Myrrh) is widely recognized for its anti-inflammatory and antimicrobial properties, which are utilized for the treatment of oral ulcers, gingivitis, sinusitis, glomerulonephritis, brucellosis and a variety of skin disorders. The current study aimed to assess whether myrrh modulates itch-associated interleukin (IL)-31 cytokine production and histamine release in stimulated human mast cells (HMC-1). To realize this, molecular biology techniques including real-time quantitiative PCR, western blotting and ELISA were employed. The results indicated that Myrrh successfully suppressed phorbol myristate acetate and calcium ionophore-stimulated mRNA expression, and reduced the production of IL-31 in HMC-1 cells. In addition, myrrh served as a suppressor of extracellular signal-regulated kinase and NF- $\mathrm{kB}$ activation, indicating its mechanism in the prevention of HMC-1 cell IL-31 production. Myrrh also prevented the release of histamine in HMC-1 cells. Whilst the present study awaits in vivo support, the pharmacological actions of myrrh provide new indications as to its potential applicability for itch treatment, which cannot be treated with histamine receptor blockers alone.
\end{abstract}

\section{Introduction}

Pruritus (itch) is the hallmark of atopic dermatitis (AD) that can severely impair patient quality of life (1). Therefore, the ultimate aim of AD management is to successfully treat itch. However, treatment is difficult due to a lack of information and an insufficient understanding of itch etiology within AD (2).

Correspondence to: Professor Seon Il Jang, Department of Health Management, Jeonju University, 303 Cheonjam-ro, Wansan-gu, Jeonju, Jeollabuk 55069, Republic of Korea

E-mail: sonjjang@jj.ac.kr

*Contributed equally

Key words: Commiphora myrrha, interleukin-31 cytokine, human mast cells, itching
A number of mediators have been implicated in the pathogenesis of AD itch, most notably including histamine, which has been extensively studied (3). Histamine is released from mast cells when tissues are inflamed or stimulated by allergens and functions to induce itch by triggering the excitation of a subset of unmyelinated C-fibers (4). Previous studies have identified four subtypes of histamine receptor coupled to guanine nucleotide-binding proteins, which include histamine receptor subtype I (H1R), histamine receptor subtype II, histamine receptor subtype III and histamine receptor subtype IV (H4R). H1R and H4R have been extensively studied and are considered to be the primary receptors that mediate $\mathrm{AD}$ itch, leading to the extensive use of their antagonists when managing and alleviating itch symptoms $(5,6)$. Histamine has been previously demonstrated to stimulate the release of various cytokines, including interleukin (IL)-1 $\alpha$ and IL-6, which have also been indicated to serve a role in itch $(7,8)$. The signaling pathway of histamine production involves phospholipase C (PLC), phosphatidylinositol 3-kinase and protein kinase $\mathrm{C}$ (PKC) (8). PLC $\gamma$ catalyzes phosphatidylinositol 4,5-bisphosphate hydrolysis, yielding diacylglycerol and inositol trisphosphate, which respectively results in PKC activation and the liberation of intracellular calcium (8). These signals subsequently lead to mast cell degranulation (8). Cytokines have also been demonstrated to induce itch and activate neuropeptide release from sensory nerves located in the skin of patients with $\operatorname{AD}(9,10)$. Previous studies have revealed a cytokine (IL-31) of the glycoprotein130/IL-6 family, which directly serves a role in AD development in mice and humans $(11,12)$. The results of the aforementioned studies indicate that transgenic mice that overexpress IL-31 or wild-type mice administered with recombinant IL-31 protein, develop characteristic skin phenotypes which mimic that of mice with $\mathrm{AD}$. Itch in $\mathrm{AD}$ has also been associated with IL-31 expression in mice. In a previous study, IL-31 mRNA was expressed in NC/Nga AD model mice, who experienced itch (13). These results indicate the importance of IL-31 in the pathogenesis of AD and particularly in itch. Until recently, various treatments have been used to relieve itch in patients with $\mathrm{AD}$ (14). The use of immunomodulators and topical applications of corticosteroids result in the cessation of itch (14). However, long-term applications may result in serious and imminent side effects such as stretch marks, 
small red/purple spots, small and dilated blood vessels on the surface of the skin and skin thinning, atrophy (14). Chronic itch is difficult to treat as current therapeutic options are frequently ineffective, which emphasizes the requirement for more effective therapeutic approaches (15). Furthermore, difficulties are experienced due to the failure of most antihistamines used in $\mathrm{AD}$ treatment, as histamine is not the sole mediator of itch (16). The requirement for new therapies for itch treatment are therefore essential.

Recently, natural plant extracts and phytochemicals have been reported to potentially prevent and treat several diseases, including AD. Commiphora myrrha (Myrrh), a member of the Burseraceae plant family, is an indigenous tree native to Somalia, Ethiopia and northern Kenya (17). Myrrh has been traditionally used in perfumes, balms for mummification, skin disease treatments and for healing wounds (18). Myrrh is also used as an anti-inflammatory and antimicrobial agent for the treatment of oral ulcers, gingivitis, sinusitis, glomerulonephritis, brucellosis and parasitic infections (19). In Germany, a herbal preparation containing myrrh, coffee and chamomile flower extracts with a well-known safety profile and has been used for $>50$ years in treatments for gastrointestinal disorders (20). A randomized clinical trial involving the same herbal preparation demonstrated that it was well tolerated in patients and demonstrated a good safety profile, while demonstrating potential efficacy for the treatment of ulcerative colitis (21). Previous studies have reported that myrrh contains biologically active metabolites, including volatile oils (eugenol, cuminic aldehyde, metacresol, pinene, diterpenes, limonene and sesquiterpenes), steroids, flavonoids, terpenoids, tannins, saponins and carbohydrates $(22,23)$. Despite the anti-inflammatory properties of myrrh extracts, their effect on itch-associated IL-31 cytokine and histamine secretion has not yet, to the best of our knowledge, been investigated. The current study hypothesized that myrrh may inhibit IL-31 and histamine secretion in phorbol-12-myristate 13-acetate (PMA) and calcium ionophore (A23187) stimulated human mast cells (HMC-1).

\section{Materials and methods}

Chemicals. Antibodies against IL-31 (cat. no. sc-515415), ERK1/2 (cat. no. sc-135900), phospho-ERK1/2 (cat. no. sc-81492), p38 (cat. no. sc-81621), phospho-p38 (cat. no. sc-166182), JNK (cat. no. sc-7345), phospho-JNK (cat. no. sc-293136), NF- $\mathrm{B} / \mathrm{p} 65$ (cat. no. sc-8008) and phospho-NF- $\kappa \mathrm{B} / \mathrm{p} 65$ (cat. no. sc-136548) were purchased from Santa Cruz Biotechnology, Inc. Antibodies against $\beta$-actin (cat. no. 612657) were purchased from Bioscience. PMA and A23187 were purchased from Sigma-Aldrich (Merck $\mathrm{KGaA}$ ). Western blotting reagent and western blotting buffer were purchased from Bio-Rad Laboratories, Inc. and Thermo Fisher Scientific, Inc., respectively. ELISA kits for IL-31 (cat. no. 445704) and histamine (cat. no. ENZKIT140-0001) were purchased from Biolegend, Inc. and Enzo Life Sciences, Inc., respectively. All subsequent chemicals used in the current study were reagent grade and have been listed within the text.

Plant extraction. Commiphora myrrha (Myrrh) was purchased from Omniherb (cat. no. MYR-1601). The plant was authenticated by Professor Kim Hong-Jun of the College of Oriental Medicine, Woosuk University (Jeollabuk-do, Republic of Korea) and a reference sample was stored in the laboratory. Following the method of a previous study (24), myrrh was extracted in $80 \%(\mathrm{~V} / \mathrm{V})$ ethanol in $2,000 \mathrm{ml}$ water for $72 \mathrm{~h}$ at room temperature on a shaker. The extracted sample was passed through filter paper with a pore size of $0.45 \mu \mathrm{m}$ (Advantec Co., Ltd.), prior to being concentrated under reduced pressure in a vacuum ( $<1$ bar). The concentrated sample was then lyophilized to obtain a powder, which was stored at $-20^{\circ} \mathrm{C}$ for subsequent use. The percentage yield of myrrh extract was $20 \%(\mathrm{w} / \mathrm{w})$.

Cell culture and treatment with myrrh. HMC-1 cells were cultured in Iscove's modified Dulbecco's medium (Gibco; Thermo Fisher Scientific) at $37^{\circ} \mathrm{C}$ with $5 \% \mathrm{CO}_{2}$ in a humidified incubator. Culture media was supplemented with $10 \%$ heat-inactivated FBS (Gibco; Thermo Fisher Scientific, Inc.) and $1 \%$ penicillin-streptomycin antibiotics (Sigma-Aldrich; Merck KGaA). Cells $\left(5 \times 10^{5}\right.$ cells $\left./ \mathrm{ml}\right)$ were seeded into sterile six or 24-well plates for $16 \mathrm{~h}$ at $37^{\circ} \mathrm{C}$ and treated with or without myrrh. This was performed $1 \mathrm{~h}$ prior to cell stimulation with $50 \mathrm{nM}$ PMA and $1 \mu \mathrm{M}$ A23187 for the indicated time periods. The control group was neither treated with myrrh extract nor stimulated with PMA+A23187. For treatment, myrrh extracts were dissolved in dimethyl sulfoxide (DMSO). The final concentration of DMSO in cells undergoing treatment was below the $<0.01 \%$ non-toxicity level.

Cell viability assay. A Water-soluble Tetrazolium salts (WST) assay was used to determine cell viability. Cells were pre-treated with various concentrations of myrrh $(0,3.125$, $6.25,12.5,25,50$ and $100 \mu \mathrm{g} / \mathrm{ml}$ ) for $24 \mathrm{~h}$ at $37^{\circ} \mathrm{C}$. A total of $0.01 \mathrm{ml}$ EZ-Cytox reagent (DoGenBio) was added and cells were subsequently incubated at $37^{\circ} \mathrm{C}$ for $4 \mathrm{~h}$. Absorbance was measured at $540 \mathrm{~nm}$ using a microplate reader (Tecan Group, Ltd.).

Reverse transcription-quantitative $(R T-q)-P C R$ analysis. HMC- 1 cells $\left(5 \times 10^{5}\right.$ cells $\left./ \mathrm{ml}\right)$ were cultured in sterile six-well dishes, pre-treated with or without myrrh at 25 and $50 \mu / \mathrm{ml}$ for $1 \mathrm{~h}$ and then stimulated with $50 \mathrm{nM}$ PMA and $1 \mu \mathrm{M}$ A23189 for $3 \mathrm{~h}$ at $37^{\circ} \mathrm{C}$. Total RNA was isolated and purified using an RNeasy Mini extraction kit (Qiagen $\mathrm{GmbH}$ ), according to the manufacturer's protocol, and stored at $-20^{\circ} \mathrm{C}$. A total of $1 \mu \mathrm{g}$ RNA from each sample was reverse transcribed to cDNA using a PrimeScript ${ }^{\mathrm{TM}}$ RT Master Mix (Takara Biotechnology Co., Ltd.) with a T100TM Thermal Cycler according to the manufacturer's protocol (Bio-Rad Laboratories, Inc.). Using specific primers for IL-31 (forward, 5'-TGTGCCAACAGA CACCCATG-3' and reverse, 3'-TGTTGGGCTCCAGAG GTCAA-5') and GADPH (forward, 5'-CACTCCTCCACC TTTGACGC-3' and reverse, 3'-TCCACCACCCTGTTGCTG TA-5') as a loading control, qPCR was performed using SYBR Premix Ex Taq ${ }^{\mathrm{TM}}$ (Takara Bio Inc.). The thermocycling conditions for RT-qPCR were as follows: $95^{\circ} \mathrm{C}$ for $3 \mathrm{~min}$ followed by 45 cycles of $95^{\circ} \mathrm{C}$ for $30 \mathrm{sec}, 60^{\circ} \mathrm{C}$ for $30 \mathrm{sec}$ and $72^{\circ} \mathrm{C}$ for $3 \mathrm{sec}$. The final extension performed at $72^{\circ} \mathrm{C}$ for $5 \mathrm{~min}$. Fluorescence data was analyzed using the $2^{-\Delta \Delta \mathrm{Cq}}$ method for relative quantification with GAPDH as a control (25). 
Western blot analysis. HMC-1 cells $\left(5 \times 10^{5}\right.$ cells $\left./ \mathrm{ml}\right)$ were cultured in sterile six-well dishes, pre-treated with or without myrrh at 25 and $50 \mu \mathrm{g} / \mathrm{ml}$ for $1 \mathrm{~h}$ and stimulated with $50 \mathrm{nM}$ PMA with the addition of $1 \mu \mathrm{M}$ A23189 for $6 \mathrm{~h}$. Whole cell proteins were extracted using radioimmunoprecipitation assay lysis buffer purchased from Thermo Fisher Scientific, Inc. The proteins were quantified using Quick Start ${ }^{\mathrm{TM}}$ Bradford $1 \mathrm{x}$ dye reagent (Bio-Rad Laboratories, Inc.). Whole cell protein lysate $(20 \mu \mathrm{g})$ was separated via electrophoresis on $12 \%$ Tris-glycine gels and transferred to polyvinylidene difluoride membranes (Immobilon; EMD Millipore). Membranes were blocked with 5\% non-fat dry milk in TBST $(0.05 \%$ Tween-20 in TBS; $\mathrm{pH}$ 7.4) for $1 \mathrm{~h}$ at room temperature and incubated with IL-31 (1:100), ERK1/2 (1:100), phospho-ERK1/2 (1:100), p38 (1:100), phospho-p38 (1:100), JNK (1:100), phospho-JNK

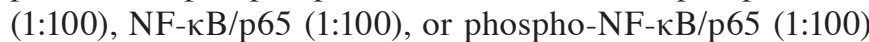
overnight at $4^{\circ} \mathrm{C}$. Blots were washed with TBST and incubated

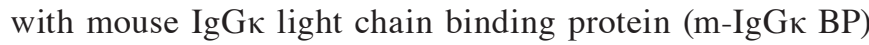
conjugated to horseradish peroxidase secondary antibodies (1:10,000; cat. no. sc-516102; Santa Cruz Biotechnology, Inc.) for $2 \mathrm{~h}$ at room temperature. Antibody-specific proteins were then visualized using an enhanced chemiluminescence detection kit (GE Healthcare). To ensure equal protein loading, the membranes were stripped and reprobed with anti- $\beta$-actin antibodies $(1: 5,000)$. The density of each immunoblot band was analyzed using ImageJ (v64-bit Java 1.8.0_112) gel analysis software (National Institutes of Health).

Measurement of cytokine and histamine production. HMC-1 cells $\left(5 \times 10^{5}\right.$ cells) were cultured in sterile 24 -well plates and pre-treated with or without at 25 and $50 \mu \mathrm{g} / \mathrm{ml}$ myrrh for $1 \mathrm{~h}$ at $37^{\circ} \mathrm{C}$. After stimulating cells with PMA+A23187 for $12 \mathrm{~h}$, the cells were centrifuged at $142 \mathrm{x}$ g for $2 \mathrm{~min}$ at $4^{\circ} \mathrm{C}$ to obtain the supernatants. The concentration of IL-31 and histamine were subsequently determined using ELISA kits. For the standard curve, recombinant IL-31 and histamine standards were run alongside the samples to calculate the concentration of IL-31 and histamine. All steps were performed at room temperature and all standards and samples were assayed in triplicate.

Statistical analysis. All data from the current study was analyzed using one-way analysis of variacnce with a Duncan's multiple range test, which were performed using SPSS version 20.0 statistical software (IBM Corp). $\mathrm{P}<0.05$ was considered to indicate a statistically significant result.

\section{Results}

Myrrh extract exhibits no cytotoxicity to pre-treated HMC-1. A WST cell viability assay was performed to evaluate the cytotoxic effects of myrrh extract in HMC-1 cells. As presented in Fig. 1, the viability of cells were assessed $4 \mathrm{~h}$ after stimulation with the WST cytotoxic reagent in the absence or presence of myrrh $(0,3.125,6.25,12.5,25,50$ and $100 \mu \mathrm{g} / \mathrm{ml})$. The results demonstrated that HMC-1 cell pre-treatment with myrrh extract did not significantly affect cell viability. Based on preliminary RT-qPCR results for IL-31 mRNA expression the concentrations of 25 and $50 \mu \mathrm{g} / \mathrm{ml}$ were chosen for subsequent experimentation.

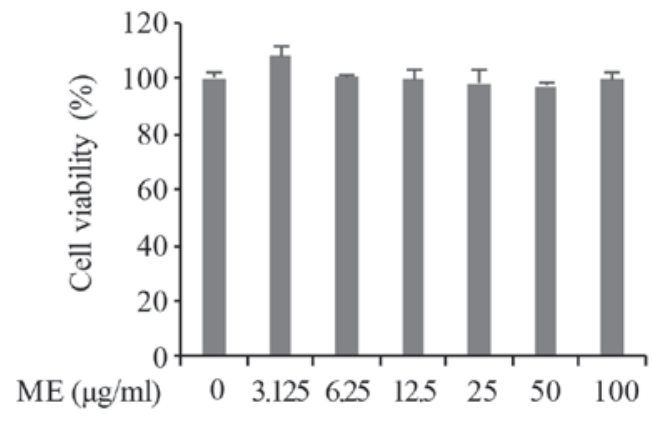

Figure 1. Effect of myrrh extract concentration on cell viability in calcium ionophore A23187-stimulated human mast cell-1 cells. Data are presented as the mean \pm standard deviation of three measurements. ME, myrrh extract.

Myrrh extract suppresses IL-31 mRNA expression. To investigate if Myrrh extract regulates IL-31 gene expression in PMA+A23187-stimulated HMC-1, cells were pre-treated with myrrh extract at 25 and $50 \mu \mathrm{g} / \mathrm{ml}$ for $1 \mathrm{~h}$ and subsequently stimulated with $50 \mathrm{nM}$ PMA and $1 \mu \mathrm{M}$ A23187 for $3 \mathrm{~h}$. As presented in Fig. 2A, PMA+A23187 significantly stimulated IL-31 mRNA expression in HMC-1 cells, while pre-treatment with myrrh extract dose-dependently and significantly inhibited PMA+A23187-induced IL-31 gene expression.

Myrrh extract suppresses IL-31 protein expression. IL-31 protein expression was investigated following treatment of PMA+A23187-stimulated HMC-1 cell samples with myrrh extract at 25 and $50 \mu \mathrm{g} / \mathrm{ml}$. Protein expression was detected $6 \mathrm{~h}$ after stimulation. As presented in Fig. 2B, PMA+A23187 significantly stimulated IL-31 protein expression in HMC-1 cells while pre-treatment with myrrh extract significantly and dose-dependently inhibited IL-31 protein expression.

Myrrh extract suppresses the production of IL-31 cytokine. The release of IL-31 in cell culture media was investigated to confirm the effect of myrrh extract on IL-31 gene and protein expression. As presented in Fig. $2 \mathrm{C}$, treatment with PMA+A23187 significantly (at $12 \mathrm{~h}$ ) stimulated IL-31 release from HMC-1 cells into the cell culture media. However, pre-treatment with myrrh at 25 and $50 \mu \mathrm{g} / \mathrm{ml}$ inhibited PMA+A23187-induced IL-31 release.

Myrrh extract inhibits histamine production. As histamine has been widely implicated in $\mathrm{AD}$ itch, the effect of myrrh extract on histamine release was also investigated in the current study. As presented in Fig. 3, treatment with PMA+A23187 significantly stimulated histamine release in HMC-1 cells. However, cells treated with myrrh extract ( 25 and $50 \mu \mathrm{g} / \mathrm{ml})$ exhibited a dose-dependent and significant decrease in histamine release.

Myrrh extract suppresses mitogen-activated protein kinases (MAPK) and NF- $\kappa B$ activation. To assess the mechanism of action of myrrh extract in the suppression of IL-31 gene expression and cytokine release, the activation of MAP kinases (p38, ERK and JNK) and NF-kB/p65 was determined. The results revealed that $\mathrm{PMA}+\mathrm{A} 23187$ significantly stimulated the phosphorylation of p38, ERK and JNK in HMC-1 cells within 30 min of stimulation (Fig. 4). However, pre-treatment 
A

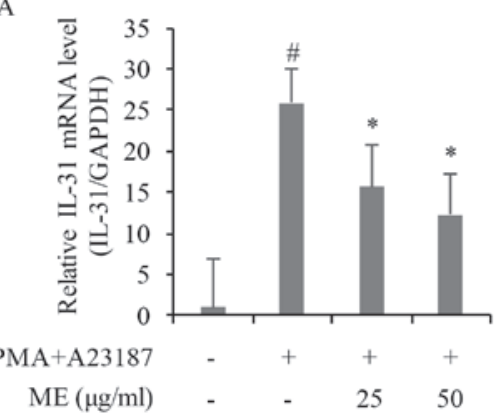

$\mathrm{C}$

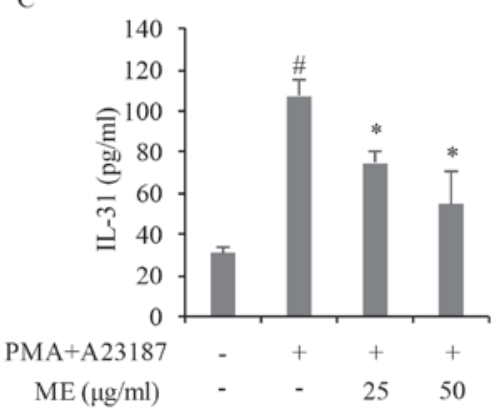

B

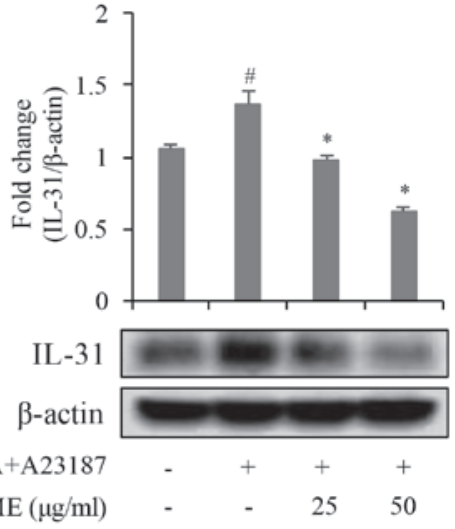

Figure 2. Effect of myrrh extract on IL-31 mRNA and protein expression in calcium ionophore A23187-stimulated human mast cell-1 cells. (A) IL-31 mRNA expression was determined by reverse transcription-quantitative PCR and (B) IL-31 cytokine protein expression was analyzed using western blot analysis. Band intensity for protein expression was normalized against $\beta$-actin. (C) ELISA analysis of IL-31 cytokine production. Data are presented as the mean \pm standard deviation of three measurements. ${ }^{~} \mathrm{P}<0.05$ vs. untreated cells; ${ }^{*} \mathrm{P}<0.05$ vs. PMA+A23187 treated cells. IL, interleukin; ME, myrrh extract; PMA, phorbol-12-myristate 13-acetate.

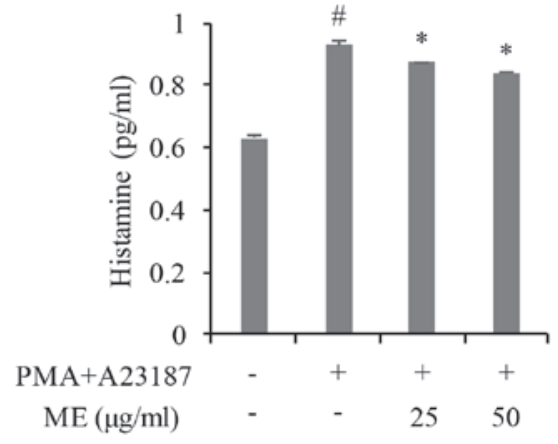

Figure 3. Effect of myrrh extract on histamine release in calcium ionophore A23187-stimulated human mast cell-1 cells. ELISA analysis of the production of histamine. Data are presented as the mean \pm standard deviation of three measurements. ${ }^{~} \mathrm{P}<0.05$ vs. untreated cells; ${ }^{*} \mathrm{P}<0.05$ vs. $\mathrm{PMA}+\mathrm{A} 23187$ treated cells. PMA, phorbol-12-myristate 13-acetate; ME, myrrh extract.

with myrrh extract significantly and dose-dependently suppressed the phosphorylation of p38, ERK, JNK and NF- $\mathrm{BB}$ (Figs. 4 and 5).

\section{Discussion}

The majority of drugs used for the treatment of itch, particularly in $\mathrm{AD}$, have been demonstrated to be ineffective. This is due to the sole targeting of the histamine pathways for which histamine is not the only mediator of itch (15). As such, there is an urgent requirement to develop drugs that will target histamine-dependent and histamine-independent itch in AD.
Drugs that are used to treat histamine-dependent itch also are typically associated with long-term side effects such as stretch marks, dilated blood vessels on the surface of the skin, skin thinning and atrophy (14). Natural extracts and compounds are known for their significant contribution to the treatment and prevention of certain diseases $(26,27)$. The current study investigated if myrrh, known for its anti-inflammatory and antibacterial activity, can inhibit itch-associated IL-31 expression and histamine release in human mast cell lines stimulated with PMA+A23187.

The results of the current study demonstrated that myrrh extract exhibited no evidence of cytotoxicity to HMC-1 in treatments up to $100 \mu \mathrm{g} / \mathrm{ml}$. As a result, myrrh extract $<100 \mu \mathrm{g} / \mathrm{ml}(25$ and $50 \mu \mathrm{g} / \mathrm{ml})$ were used to demonstrate the effects on stimulated-HMC-1 cells. The results of the present study indicated that myrrh extract significantly inhibited the expression of IL-31 mRNA in comparison with the control group. The effect of myrrh on IL-31 protein expression and release in HMC-1 cells was also investigated. Myrrh was demonstrated to inhibit the expression and release of IL-31 in HMC-1 cells. The results also demonstrated that the inhibitory effects of myrrh in IL-31 production start at the level of gene expression. Myrrh and myrrh oils have been previously demonstrated to exhibit anti-inflammatory effects by inhibiting the production of prostaglandin E2, nitrous oxide and proinflammatory cytokines including tumor necrosis factor (TNF)- $\alpha$, IL-6 and IL-8, in other cell lines including peripheral macrophages, human gingival fibroblasts and epithelial cells within in vivo studies (28-30). To understand the mechanisms of action used by myrrh 

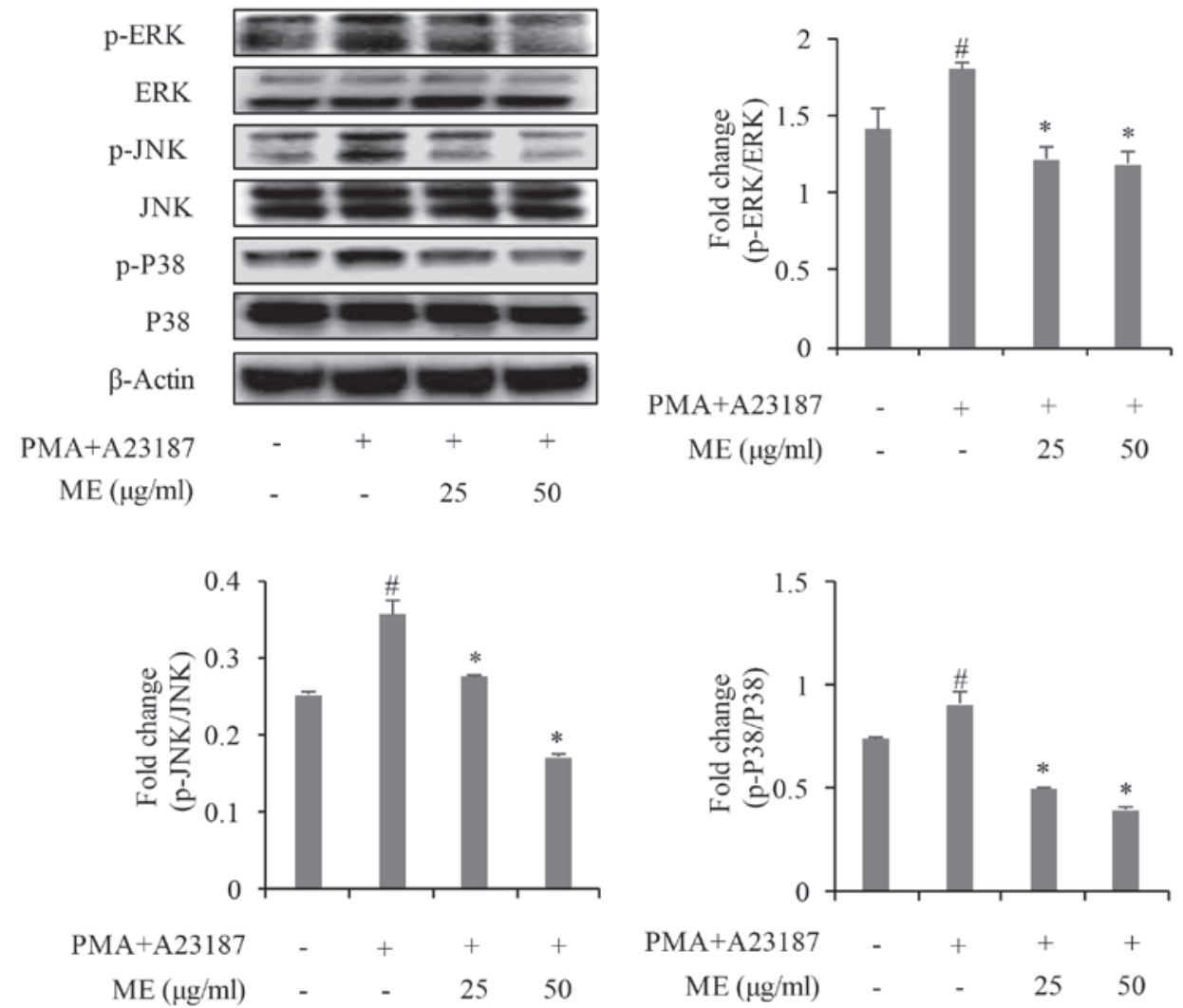

Figure 4. Effect of myrrh extract on the activation of mitogen-activated protein kinases. Western blotting was performed to analyze the phosphorylation of ERK, 38 and JNK. ERK results were quantified using ImageJ software and the band intensity for each protein expression was normalized against $\beta$-actin. Data are presented as the mean \pm standard deviation of three measurements. ${ }^{\prime \prime} \mathrm{P}<0.05$ vs. untreated cells; ${ }^{*} \mathrm{P}<0.05$ vs. PMA+A23187 treated cells. p, phosphorylated; PMA, phorbol-12-myristate 13-acetate; ME, myrrh extract.

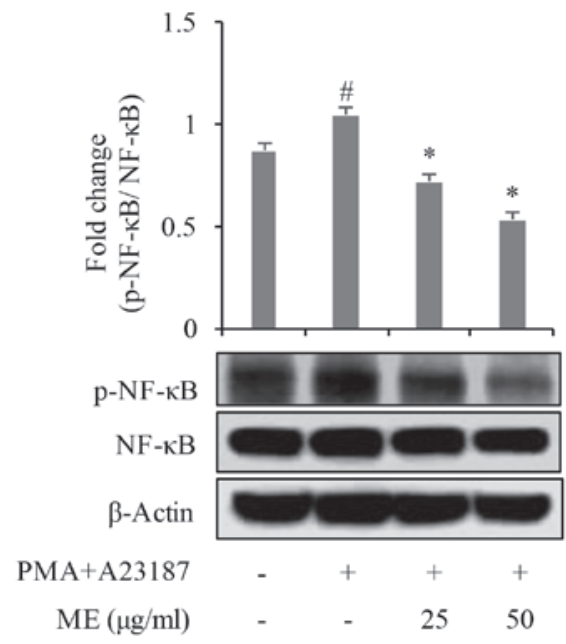

Figure 5. Effect of myrrh extract on the activation of NF-кB. The phosphorylation of NF- $\mathrm{kB}$ was analyzed using western blot analysis. The results were quantified using ImageJ software. Band intensity for each protein expression was normalized against $\beta$-actin. Data are presented as the mean \pm standard deviation of three measurements. ${ }^{*} \mathrm{P}<0.05$ vs. untreated cells; ${ }^{*} \mathrm{P}<0.05$ vs PMA+A23187 treated cells. p, phosphorylated; PMA, phorbol-12-myristate 13-acetate; ME, myrrh extract.

extract in inhibiting itch-associated IL-31 further, the effects of myrrh extract on $\mathrm{NF}-\kappa \mathrm{B}$ and MAPK activation was assessed. The MAPK cascade is a signaling pathway of the immune response and serves an essential role in the intracellular signal network, while also regulating cytokine expression (31). NF- $\kappa \mathrm{B}$ serves a role in the regulation of cell survival genes and the coordination of proinflammatory cytokine expression including in TNF- $\alpha$ and IL-6 (32). MAPK has also been implicated in NF- $\kappa \mathrm{B}$ activation (33). It has been previously demonstrated that MAPK and $\mathrm{NF}-\kappa \mathrm{B} / \mathrm{p} 65$ activation drive IL-31 production and secretion, as potent inhibitors of MAPK and NF- $\kappa$ B block IL-31 release in HMC-1 cells (34). A novel NF- $\mathrm{BB}$-binding element within the IL-31 promoter has also been revealed to mediate IL-31 expression in human T helper 2 cells (35). Major compounds found in myrrh, which include flavonoids, sesquiterpene, terpenoids and eugenol, have been revealed to inhibit the activation of the MAPK and NF- $\kappa \mathrm{B}$ pathways (36-39). In the current study, the results indicated that myrrh extract inhibited the PMA+A23187-induced phosphorylation of JNK, ERK and p38. Myrrh extract also inhibited the phosphorylation of $\mathrm{NF}-\kappa \mathrm{B}$, indicating that the action of myrrh extract in the inhibition of PMA+A23187-induced production of IL-31 is mediated by its inhibition of the MAPK and NF- $\kappa$ B signaling pathways.

Since histamine is released from mast cells when tissues are inflamed or stimulated by AD allergens, serving to mediate the histamine-induced itch response, the current study also assessed the effect of myrrh extract on histamine release from mast cells stimulated with PMA+A23187. PMA+A23187 has been previously demonstrated to stimulate the release 
of histamine in HMC-1 cells (40). In the present study, the PMA+A23187 stimulation of mast cell histamine release was revealed and myrrh extract was demonstrated to inhibit this release. The results of the current study may raise the awareness of myrrh and the ability of its active compounds to target histamine-dependent and histamine-independent itch, particularly in cases where histamine receptor blockers alone are ineffective in alleviating itch.

In the present study, it was demonstrated that an anti-inflammatory effect of myrrh is the regulation of the itch-associated IL-31 cytokine release. It was also demonstrated that myrrh may be associated with the reduction of intracellular MAPK and NF- $\kappa \mathrm{B} / \mathrm{p} 65$ activation in PMA+A23187-activated HMC-1 cells. The results also revealed that myrrh inhibits histamine release in activated HMC-1 cells. The current study provides new evidence as to the anti-itch mechanism of myrrh, which has been previously used as a treatment for other skin infections, inflammatory conditions, periodontal, diarrhea and allergic diseases (41). Conclusively, it can be expected that myrrh and its active compounds may be considered a viable candidate in AD itch treatment due to its action on mast cells. However, the current study was performed on a single cell line (HMC-1). Further studies involving other associated cell lines, including primary mast cells and in vivo experiments mimicking symptoms like itch in $\mathrm{AD}$, are therefore required to ascertain these claims.

\section{Acknowledgements}

Not applicable.

\section{Funding}

The present study was supported by project for Cooperative R\&D between Industry, Academy and Research Institute funded Korea Ministry of SMEs and Startups in 2017 (grant no. C0506751).

\section{Availability of data and materials}

The analyzed data sets generated during the present study are available from the corresponding author on reasonable request.

\section{Authors' contributions}

$\mathrm{BC}$ and SJ designed the current study and analyzed the data. JS, DC, HK and JK performed the experiments. JS, DC and $\mathrm{BC}$ wrote the manuscript. SJ managed the research project.

\section{Ethics approval and consent to participate}

Not applicable.

\section{Patient consent for publication}

Not applicable.

\section{Competing interests}

The authors declare that they have no competing interests.

\section{References}

1. Yosipovitch G and Papoiu AD: What causes itch in atopic dermatitis? Curr Allergy Asthma Rep 8: 306-311, 2008.

2. Sanders KM, Nattkemper LA and Yosipovitch G: Advances in understanding itching and scratching: A new era of targeted treatments. F1000Res 5: F1000 Faculty Rev-2042, 2016.

3. Mollanazar NK, Smith PK and Yosipovitch G: Mediators of chronic pruritus in atopic dermatitis: Getting the itch out? Clin Rev Allergy Immunol 51: 263-292, 2016.

4. Tani E, Shiosaka S, Sato M, Ishikawa T and Tohyama M: Histamine acts directly on calcitonin gene-related peptide- and substance P-containing trigeminal ganglion neurons as assessed by calcium influx and immunocytochemistry. Neurosci Lett 115: 171-176, 1990.

5. Dunford PJ, Williams KN, Desai PJ, Karlsson L, McQueen D and Thurmond RL: Histamine H4 receptor antagonists are superior to traditional antihistamines in the attenuation of experimental pruritus. J Allergy Clin Immunol 119: 176-183, 2007.

6. Simons FE, Simons KJ, Becker AB and Haydey RP: Pharmacokinetics and antipruritic effects of hydroxyzine in children with atopic dermatitis. J Pediatr 104: 123-127, 1984.

7. Stempelj M and Ferjan I: Signaling pathway in nerve growth factor induced histamine release from rat mast cells. Inflamm Res 54: 344-349, 2005.

8. Metcalfe DD, Peavy RD and Gilfillan AM: Mechanisms of mast cell signaling in anaphylaxis. J Allergy Clin Immunol 124: 639-646; quiz 647-648, 2009.

9. Nemeth K, Wilson T, Rada B, Parmelee A, Mayer B, Buzas E, Falus A, Key S, Masszi T, Karpati S and Mezey E: Characterization and function of histamine receptors in human bone marrow stromal cells. Stem Cells 30: 222-231, 2012.

10. Nordlind K, Chin LB, Ahmed AA, Brakenhoff J, Theodorsson E and Liden S: Immunohistochemical localization of interleukin-6-like immunoreactivity to peripheral nerve-like structures in normal and inflamed human skin. Arch Dermatol Res 288: 431-435, 1996.

11. Stevens SR, Hanifin JM, Hamilton T, Tofte SJ and Cooper KD: Long-term effectiveness and safety of recombinant human interferon gamma therapy for atopic dermatitis despite unchanged serum IgE levels. Arch Dermatol 134: 799-804, 1998.

12. Zhang Q, Putheti P, Zhou Q, Liu Q and Gao W: Structures and biological functions of IL-31 and IL-31 receptors. Cytokine Growth Factor Rev 19: 347-356, 2008.

13. Takaoka A, Arai I, Sugimoto M, Yamaguchi A, Tanaka M and Nakaike S: Expression of IL-31 gene transcripts in NC/Nga mice with atopic dermatitis. Eur J Pharmacol 516: 180-181, 2005.

14. Weidinger S, Beck LA, Bieber T, Kabashima K and Irvine AD: Atopic dermatitis. Nat Rev Dis Primers 4: 1, 2018.

15. Lee $\mathrm{CH}$ : Progress of pruritus research in atopic dermatitis. Biomol Ther 18: 246-256, 2010.

16. Rukwied R, Lischetzki G, McGlone F, Heyer G and Schmelz M: Mast cell mediators other than histamine induce pruritus in atopic dermatitis patients: A dermal microdialysis study. Br J Dermatol 142: 1114-1120, 2000.

17. Başer KHC, Demirci B, Dekebo A and Dagne E: Essential oils of some Boswellia spp., Myrrh and Opopanax. Flavour Fragr J 18: 153-156, 2003.

18. Ljaljević Grbić M, Unković N, Dimkić I, Janaćković P, Gavrilović M, Stanojević O, Stupar M, Vujisić L, Jelikić A, Stanković S and Vukojević J: Frankincense and myrrh essential oils and burn incense fume against micro-inhabitants of sacral ambients. Wisdom of the ancients? J Ethnopharmacol 219: 1-14, 2018.

19. Mohamed AA, Ali SI, El-Baz FK, Hegazy AK and Kord MA: Chemical composition of essential oil and in vitro antioxidant and antimicrobial activities of crude extracts of Commiphora myrrha resin. Industr Crops Prod 57: 10-16, 2014.

20. Albrecht U, Muller V, Schneider B and Stange R: Efficacy and safety of a herbal medicinal product containing myrrh, chamomile and coffee charcoal for the treatment of gastrointestinal disorders: A non-interventional study. BMJ Open Gastroenterol 1: e000015, 2015.

21. Langhorst J, Varnhagen I, Schneider SB, Albrecht U, Rueffer A, Stange R, Michalsen A and Dobos GJ: Randomised clinical trial: A herbal preparation of myrrh, chamomile and coffee charcoal compared with mesalazine in maintaining remission in ulcerative colitis-a double-blind, double-dummy study. Aliment Pharmacol Ther 38: 490-500, 2013. 
22. Shameem I: Phytochemical \& therapeutic potentials of Murr Makki (Commiphora myrrha): A review. Indian J Appl Res 8: 102-104, 2018.

23. Hanus LO, Rezanka T, Dembitsky VM and Moussaieff A Myrrh-Commiphora chemistry. Biomed Papers Med Faculty Univ Palacky, Olomouc, Czechoslovakia 149: 3-27, 2005.

24. Baek SJ and Kim DH: The Study on anti-obesity of Myrrh ethanol extract. Korea J Herbol 31: 11-18, 2016.

25. Livak KJ and Schmittgen TD: Analysis of relative gene expression data using real time quantitative PCR and the 2(-Delta Delta $\mathrm{C}(\mathrm{T})$ ) method. Methods 25: 402-408, 2001.

26. Jamshidi-Kia F, Lorigooini $\mathrm{Z}$ and Amini-Khoei H: Medicinal plants: Past history and future perspective. J Herbmed Pharmacol 7: 1-7, 2018.

27. Panche AN, Diwan AD and Chandra SR: Flavonoids: An overview. J Nutr Sci 5: e47, 2016.

28. Kim MS, Bae GS, Park KC, Koo BS, Kim BJ, Lee HJ, Seo SW, Shin YK, Jung WS, Cho JH, et al: Myrrh inhibits LPS-induced inflammatory response and protects from cecal ligation and puncture-induced sepsis. Evid Based Complement Alternat Med 2012: 278718, 2012.

29. Tipton DA, Lyle B, Babich H and Dabbous MKh: In vitro cytotoxic and anti-inflammatory effects of myrrh oil on human gingival fibroblasts and epithelial cells. Toxicol In Vitro 17: 301-310, 2003.

30. Fatani AJ, Alrojayee FS, Parmar MY, Abuohashish HM, Ahmed MM and Al-Rejaie SS: Myrrh attenuates oxidative and inflammatory processes in acetic acid-induced ulcerative colitis. Exp Ther Med 12: 730-738, 2016.

31. Kawakami Y, Hartman SE, Holland PM, Cooper JA and Kawakami T: Multiple signaling pathways for the activation of JNK in mast cells: Involvement of Bruton's tyrosine kinase, protein kinase C and JNK kinases, SEK1 and MKK7. J Immunol 161: 1795-1802, 1998.

32. Park HJ, Lee HJ, Choi MS, Son DJ, Song HS, Song MJ, Lee JM, Han SB, Kim Y and Hong JT: JNK pathway is involved in the inhibition of inflammatory target gene expression and NF-kappaB activation by melittin. J Inflamm (Lond) 5: 7, 2008.
33. Craig R, Larkin A, Mingo AM, Thuerauf DJ, Andrews C, McDonough PM and Glembotski CC: p38 MAPK and NF-kappa $\mathrm{B}$ collaborate to induce interleukin-6 gene expression and release. Evidence for a cytoprotective autocrine signaling pathway in a cardiac myocyte model system. J Biol Chem 275: 23814-23824, 2000.

34. Che DN, Cho BO, Shin JY, Kang HJ, Kim YS and Jang SI: Fisetin inhibits IL-31 production in stimulated human mast cells: Possibilities of fisetin being exploited to treat histamine-independent pruritus. Life Sci 201: 121-129, 2018.

35. MaierE,Werner D,Duschl A, Bohle B and Horejs-Hoeck J: Human

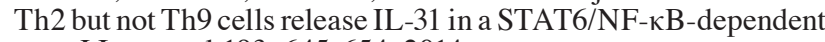
way. J Immunol 193: 645-654, 2014.

36. Wang Y, Zhou B, Lu J, Chen Q, Ti H, Huang W, Li J, Yang Z, Jiang $Z$ and Wang $X$ : Inhibition of influenza virus via a sesquiterpene fraction isolated from Laggera pterodonta by targeting the NF- $\mathrm{KB}$ and $\mathrm{p} 38$ pathways. BMC Complement Altern Med 17: $25,2017$.

37. Salminen A, Lehtonen M, Suuronen T, Kaarniranta K and Huuskonen J: Terpenoids: Natural inhibitors of NF-kappaB signaling with anti-inflammatory and anticancer potential. Cell Mol Life Sci 65: 2979-2999, 2008.

38. Deepak V, Kasonga A, Kruger MC and Coetzee M: Inhibitory effects of eugenol on RANKL-induced osteoclast formation via attenuation of NF- $\mathrm{kB}$ and MAPK pathways. Connect Tissue Res 56: 195-203, 2015.

39. Karunaweera N, Raju R, Gyengesi E and Münch G: Plant polyphenols as inhibitors of $\mathrm{NF}-\kappa \mathrm{B}$ induced cytokine production-a potential anti-inflammatory treatment for Alzheimer's disease? Front Mol Neurosci 8: 24, 2015.

40. Je IG, Kim HH, Park PH, Kwon TK, Seo SY, Shin TY and Kim SH: SG-HQ2 inhibits mast cell-mediated allergic inflammation through suppression of histamine release and pro-inflammatory cytokines. Exp Biol Med (Maywood) 240: 631-638, 2015.

41. Nomicos EY: Myrrh: Medical marvel or myth of the Magi? Holist Nurs Pract 21: 308-323, 2007. 